\section{Screening Sweet Cherry Selections for Dormant Floral Bud Hardiness}

\author{
Sorkel A. Kadir ${ }^{1}$ \\ Mount Vernon Research and Extension Unit, 1468 Memorial Highway, Mount \\ Vernon, WA 98273-9788
}

\author{
Edward L. Proebsting ${ }^{2}$ \\ Irrigated Agriculture Research and Extension Center, Presser, WA 99350
}

Additional index words. differential thermal analysis, flower buds, Prunus avium, supercooling

\begin{abstract}
In Dec. 1990, sweet cherry (Prunus avium L.) selections varied in floral bud kill from $9 \%$ to $92 \%$ following exposure to severe cold. In the following winter, the hardiness of two hardy and two tender selections was analyzed by differential thermal analysis (DTA) to screen selections for hardiness. In a mild winter, when buds remained at their minimum hardiness level, the hardy selections consistently were $>2 \mathrm{C}$ hardier than the tender selections. About one-half of that hardiness difference was associated with differences in tissue water content, the other half with unknown factors. Buds of the tender selections began to develop earlier and bloomed earlier than the hardy selections. DTA analysis of floral bud populations separated selections that clearly differed in floral bud hardiness.
\end{abstract}

Yield of sweet cherries in Washington is determined primarily by low-temperature injury to floral buds or flowers. Frost protection measures (wind machines, sprinklers, and heaters) me a major production cost, with $13 \%$ of orchard operating costs attributed to this expense (Hinman et al., 1983). Using cold-resistant cultivars as a means to reduce losses from low-temperature injury has not been considered in this area, where 'Bing' is the dominant cultivar, but new selections adapted to central Washington may make this feasible.

To screen cultivars and selections for cold hardiness, tissue must be tested regularly. Laboratory testing of hardiness is widely used but rarely compared with field results. For laboratory comparisons of cultivars and selections to be representative of their response to field conditions, the link between field and laboratory testing must be firmly established.

In Dec. 1990, temperatures dropped to $-21.7 \mathrm{C}$ following a period of warm days, causing losses of $50 \%$ to $80 \%$ of 'Bing' floral buds (Proebsting, 1992). Many selections from the breeding program at the Irrigated Agriculture Research and Extension Center (IAREC), Presser, Wash., sustained less injury than 'Bing' in this freeze. The objectives of this study were to 1) screen selections for cold hardiness using differential thermal analysis

Received for publication 9 Apr. 1993. Accepted for publication 11 Aug. 1993. Horticulture and Landscape Architecture scientific paper no. 92-19, project 0215, Washington State College of Agriculture Research Center. This research was supported in part by a grant from the Washington Tree Fruit Research commission. The cost of publishing this paper was defrayed in part by the payment of page charges. Under postal regulations, this paper therefore must be hereby marked advertisement solely to indicate this fact.

${ }^{\mathrm{I}}$ To whom reprint requests should be addressed. ${ }^{2}$ Horticulturist.
(DTA), then compare them with field results obtained during the arctic advective freeze of Dec. 1990 and 2) assess the role of tissue water content on cold hardiness of the selections. We chose two selections that survived the Dec. 1990 freeze and one selection that was injured more than 'Bing' to use in laboratory tests during Winter 1991-92.

\section{Materials and Methods}

Duplicate floral bud samples for DTA and water content were collected from Dec. 1991 to Mar. 1992 from trees of Presser selections 7144-3, 7147-13, and 7309-4, which were compared with 'Bing'. The trees were planted in 1983 at the IAREC. In Dec. 1990, low temperatures killed 9\% (7144-3), 12\% (7147-13), 66\% ('Bing'), and 92\% (7309-4) of the floral buds of these selections, based on visual observations.

Samples were collected, sealed in plastic bags, placed immediately on ice for transport, and prepared in a freezer for the DTA test. About 10 to 15 floral buds were cut from twigs, along with 1 to $2 \mathrm{~mm}$ of bark tissue, and placed on both sides of a thermoelectric module (Melcor Electronic Products Crop., Trenton, N. J.) (Andrews et al., 1983). Buds were held in place with aluminum foil. Heat flux plates were frozen as reported by Kader and Proebsting (1992) at a cooling rate of $4 \mathrm{C} / \mathrm{h}$.

Samples were removed from the freezer the next day and placed in a $100 \%$ relative humidity chamber at room temperature (23C) for $24 \mathrm{~h}$ before florets per floral bud were counted. The extent of supercooling of the floral bud population was expressed as the temperature at which $50 \%$ of primordia were injured $\left(\mathrm{LTE}_{50}\right)$ (Andrews and Proebsting, 1987). Maximum $\mathrm{LTE}_{50}$, or the minimum hardiness level (MHL), was recorded during the dormant period. The percentage of floral pri- mordia that supercooled was expressed as the ratio of the number of low-temperature exotherms (LTEs) to the number of floral primordia within the sample (LTE/primordium). The daily minimum and maximum air temperatures of the orchard were obtained from an automated weather station located $500 \mathrm{~m}$ west of the test orchard. Water content was determined by drying the floral buds at $90 \mathrm{C}$ for $24 \mathrm{~h}$ and was expressed as a percentage of dry weight.

The experiment was a randomized complete block design with a $4 \times 8$ factorial arrangement (cultivar $\times$ date) and six replications. The data were analyzed using standard analysis of variance or regression analyses as appropriate. Least significant differences (LSD) among means were tested at $P=0.05$.

\section{Results and Discussion}

LTEs were observed for each sweet cherry selection. The $\mathrm{LTE}_{50}$ of 7144-3 and 7147-13 was $-23 \mathrm{C}$ in early December, whereas 'Bing' and 7309-4 floral buds supercooled only to -20.9 and $-20.6 \mathrm{C}$, respectively (Table 1 ). Throughout the season, a consistent difference in $\mathrm{LTE}_{50}$ was observed between the selections. Floral buds of 7144-3 and 7147-13 were

Table 1. The median low-temperature exotherm $\left(\mathrm{LTE}_{50}\right)$, percentage of primordia that supercooled (LTE/primordium), and water content (percent dry weight) of floral buds of three sweet cherry selections and 'Bing' during Winter 199192.

\begin{tabular}{|c|c|c|c|c|}
\hline Date & Selection & $\begin{array}{c}\text { LTE }_{50} \\
\left({ }^{\circ} \mathrm{C}\right)\end{array}$ & $\begin{array}{c}\text { LTE/ } \\
\text { primordium } \\
(\%)\end{array}$ & $\begin{array}{c}\text { Water } \\
\text { content } \\
(\% \text { dry wt }) \\
\end{array}$ \\
\hline \multirow[t]{4}{*}{10 Dec. } & $7144-3$ & $-23.0^{z}$ & 88 & 100 \\
\hline & $7147-13$ & -23.0 & 83 & 100 \\
\hline & Bing & -20.9 & 89 & 103 \\
\hline & $7309-4$ & -20.6 & 69 & 111 \\
\hline \multirow[t]{4}{*}{15 Dec. } & $7144-3$ & -22.3 & 75 & 102 \\
\hline & $7147-13$ & -22.9 & 88 & 99 \\
\hline & Bing & -20.3 & 77 & 105 \\
\hline & $7309-4$ & -20.3 & 73 & 103 \\
\hline \multirow[t]{4}{*}{23 Dec. } & 7144-3 & -20.7 & 86 & 110 \\
\hline & $7147-13$ & -21.1 & 86 & 111 \\
\hline & Bing & -19.2 & 81 & 111 \\
\hline & $7309-4$ & -17.5 & 86 & 117 \\
\hline \multirow[t]{4}{*}{28 Jan. } & $7144-3$ & -19.5 & 87 & 108 \\
\hline & $7147-13$ & -19.9 & 78 & 108 \\
\hline & Bing & -17.8 & 77 & 117 \\
\hline & $7309-4$ & -17.3 & 73 & 119 \\
\hline \multirow[t]{3}{*}{6 Feb. } & $7144-3$ & -19.2 & 89 & 107 \\
\hline & $7147-13$ & -19.8 & 75 & 106 \\
\hline & Bing & -17.7 & 82 & 118 \\
\hline \multirow[t]{4}{*}{20 Feb. } & $7144-3$ & -16.1 & 77 & 132 \\
\hline & $7147-13$ & -15.9 & 63 & 138 \\
\hline & Bing & -14.4 & 48 & 151 \\
\hline & $7309-4$ & -13.9 & 56 & 162 \\
\hline \multirow[t]{4}{*}{2 Mar. } & $7144-3$ & -14.2 & 76 & $---y$ \\
\hline & $7147-13$ & -13.9 & 51 & -- \\
\hline & Bing & -11.7 & 31 & --- \\
\hline & $7309-4$ & -12.4 & 26 & -- \\
\hline \multirow[t]{4}{*}{9 Mar. } & $7144-3$ & -12.3 & 31 & -- \\
\hline & $7147-13$ & -13.9 & 26 & -- \\
\hline & Bing & $--^{x}$ & --- & --- \\
\hline & $7309-4$ & --- & --- & --- \\
\hline $\mathrm{LSD}_{0.05}$ & & 1 & 16 & 11 \\
\hline
\end{tabular}

${ }^{2}$ Values are means of six observations.

${ }^{y}$ Not tested at this date

${ }^{x}$ No LTEs detected. 
hardier than those of 'Bing' or 7309-4, as had been observed in 1990 in the field. No LTEs were detected from 'Bing' and 7309-4 floral buds on 9 Mar. A maximum LTE s0 , or MHL, was established early in the dormant period and stayed constant during late fall and winter, then rose in early spring as the bud developed (Proebsting, 1963, 1970). The MHL of floral buds of the hardy selections was constant (-24.6C) during early and mid-December of the mild Winter 199 1-92.

About a $2 \mathrm{C}$ increase in $\mathrm{LTE}_{50}$ between December and January was detected in the floral buds of all four selections (Table 1). The lowest air temperature of Winter 1991-92 was $-6.7 \mathrm{C}$ on 17 Dec. During January and February, MHL increased significantly and continued to increase until 9 Mar. The $\mathrm{LTE}_{50}$ of 'Bing' and 7309-4 floral buds increased by 1 and $3 \mathrm{C}$ in late December, respectively, and continued to increase until no LTEs were detected on 9 Mar.

Floral bud hardiness has been negatively related to tissue moisture content (Andrews and Proebsting, 1987; Quamme, 1983). This relationship is evident in the combined data of Dec. 1991 through Feb. 1992 (Fig. 1). These differences in $\mathrm{LTE}_{50}$ can be attributed to the stage of development as reflected by differences in tissue water content. Eliminating the effect of development stage by using only data from December makes the cultivar effects obvious (Fig. 2). During December, the two tender selections had a mean $\mathrm{LTE}_{50}$ of $-19.8 \mathrm{C}$, whereas the two hardy selections' mean was $-22.2 \mathrm{C}$ (Table 1 ) - a 2.4C difference in hardiness. Calculating the intercept at 105910 water content from the regressions in Fig. 2, the two hardy selections had an average $\mathrm{LTE}_{50}$ of $-21.8 \mathrm{C}$, and the tender selections $-20.7 \mathrm{C}-\mathrm{a}$ difference of $1.1 \mathrm{C}$. Therefore, a $1.3 \mathrm{C}$ difference is not accounted for by differences in moisture content. The hardy selections were more tolerant than the tender selections partly because of lower moisture content, but also partly because of unknown factors.

The number of florets in a sample does not always correspond to the number of LTEs produced; therefore, florets per floral bud were counted to calculate the percentage of florets that supercooled (LTE/primordium). The capacity of "the selections' floral buds to deep supercool (LTE/primordium) was constant from December until late February (Table 1). The percentage of LTE/primordium stabilized near $75 \%$ to $90 \%$ until a significant decrease occurred in late February for 'Bing' and 7309-4 and 1 month later for the hardy selections, indicating earlier bud development in the more tender selections that might be due to vascular system development in the bud axis (Ashworth, 1984).

Our study showed that DTA of floral bud hardiness for the selections supports the visual field observations of hardiness. This result supports using this method to estimate floral bud hardiness for screening breeding populations. The differences in hardiness were constant throughout the dormant season, which suggests that testing could proceed through the winter.

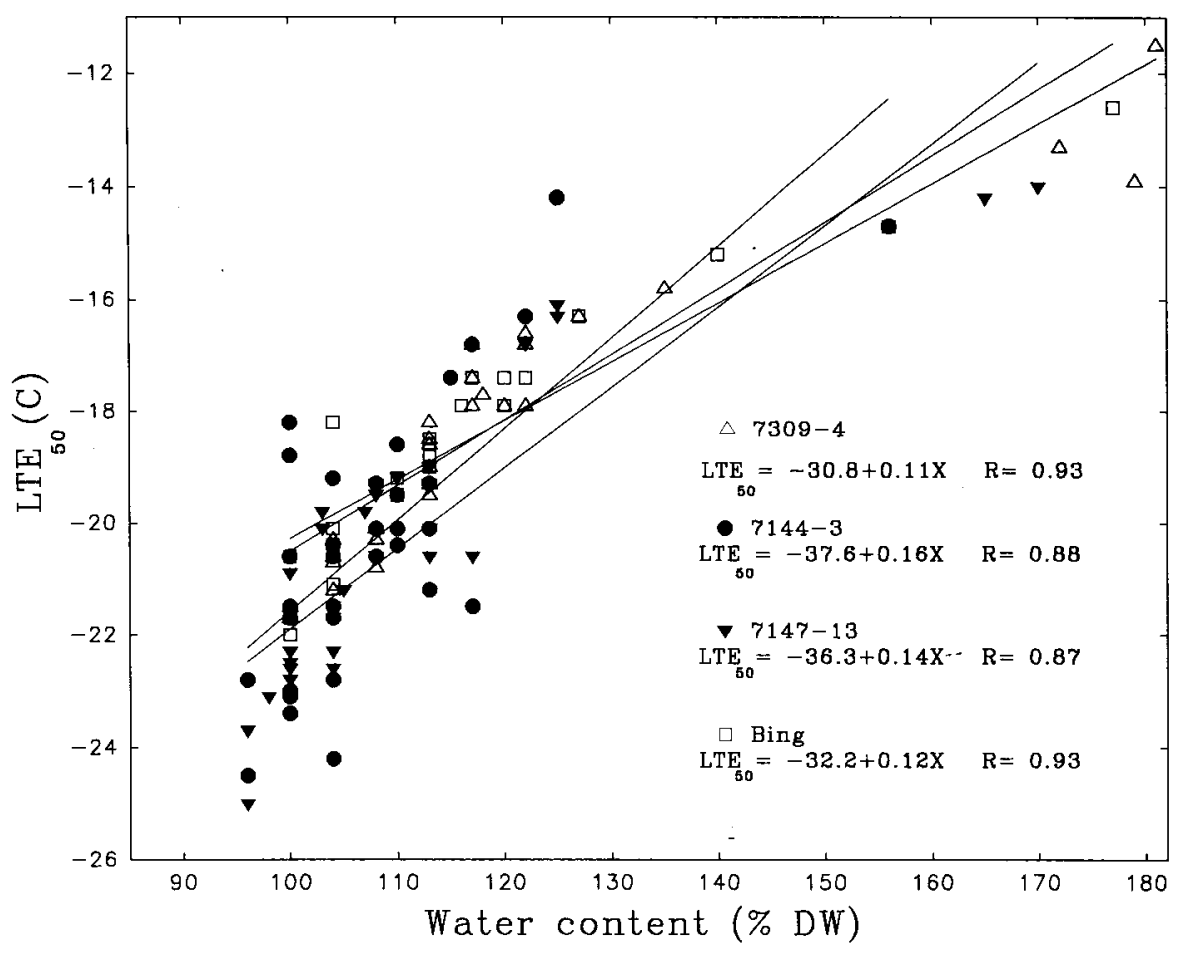

Fig, 1, The relationship between water content (percent dry weight) of floral buds and the median lowtemperature exotherm $\left(\mathrm{LTE}_{\mathrm{s} 0}\right)$ of three sweet cherry selections and 'Bing' during Winter 1991-92.

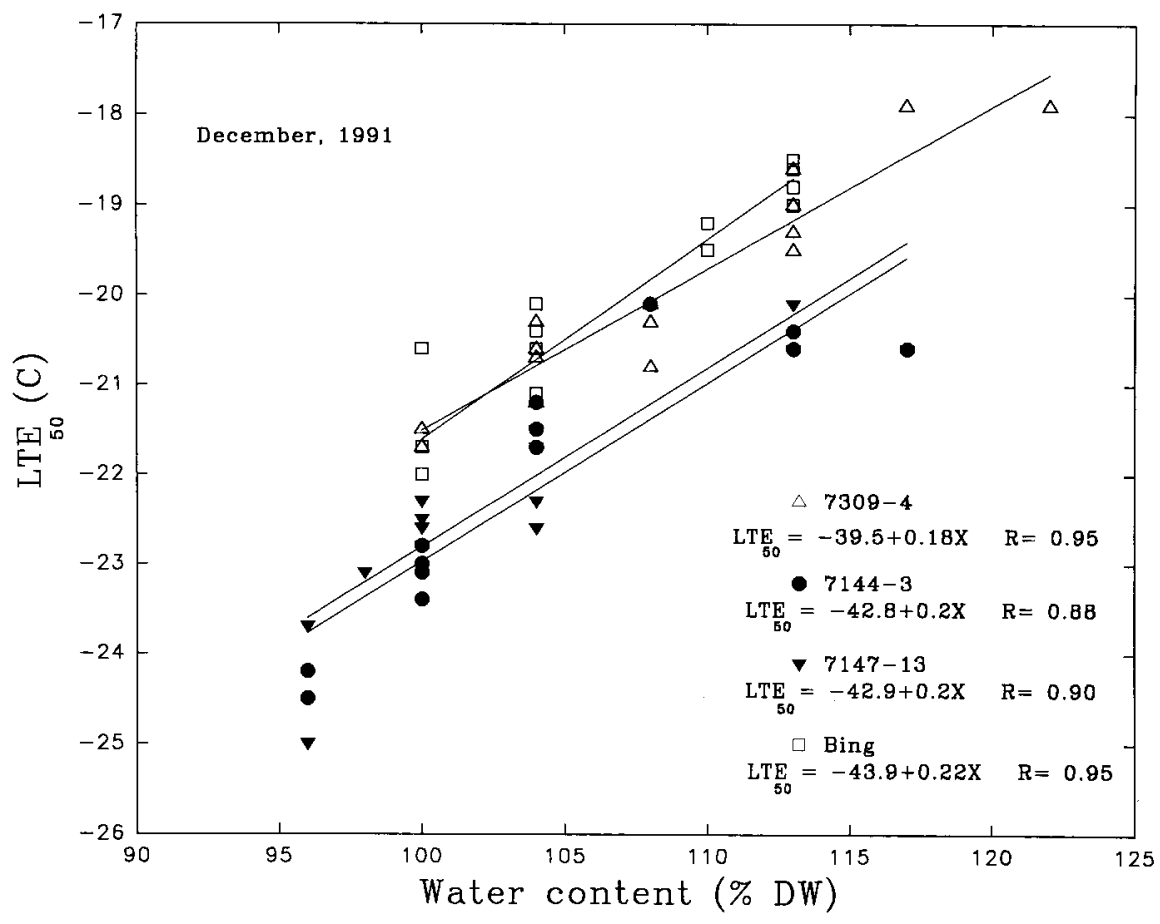

Fig. 2. The relationship between water content (percent dry weight) of floral buds and the median low. temperature exotherm (LTE50) of three sweet cherry selections and 'Bing' during Dec. 1991. 


\section{Literature Cited}

Andrews, PK. and E.L. Proebsting. 1987. Effects of temperature on the deep supercooling characteristics of dormant and reacclimating sweet cherry flower buds. J. Amer. Soc. Hort. Sci. 112;334-340.

Andrews, P. K., E.L. Proebsting, and G.S. Campbell, 1983. An exotherm sensor for measuring the cold hardiness of deep supercooled flower buds by differential thermal analysis. HortScience 18:77-78.

Ashworth, E.N. 1984. Xylem development in Prunus flower buds and the relationship to deep supercooling. Plant Physiol. 74: 862-865.

Hinman, H. R., R.B. Tukey, J. W. Watson, Jr., and A.B. Peterson. 1983. Estimated costs of producing sweet cherries in central Washington. Washington State Univ. Ext. Bul. 1222.

Kader, S.A. and E.L. Proebsting. 1992. Freezing behavior of Prunus, subgenus Padus, flower buds. J. Amer. Soc. Hort. Sci. 117:955-960.

Proebsting, E, 1992, Effects of winter, 1990-1991 freeze temperatures and plant resistance. Proc. Wash. State Hort. Assn. 87: 158-160,
Proebsting, E. L., Jr. 1963. The role of air temperatures and bud development in determining hardiness of dormant Elberta peach fruit buds. Proc. Amer. Soc. Hort. Sci. 83:259-269.

Proebsting, E. L., Jr, 1970. Relation of fall and winter temperatures to flower bud behavior and wood hardiness of deciduous fruit trees, HortScience 5:422-424.

Quamme, H.A. "1983. Relationship of air temperature to water content and supercooling of overwintering peach flower buds. J. Amer. Soc. Hort. Sci. 108:697-701. 